Research Article

\title{
Research on the Expansion Characteristics and Compressive Strength of Mortars Containing Circulating Fluidized Bed Combustion Desulfurization Slag
}

\author{
Zhi Cheng $\mathbb{D}^{1,2}$ Zhijun Cheng $\mathbb{D},{ }^{2}$ Hua Hou, ${ }^{1}$ Tao Han, ${ }^{1}$ and Lan Liu ${ }^{2}$ \\ ${ }^{1}$ School of Materials Science and Engineering, North University of China, Taiyuan 030051, China \\ ${ }^{2}$ School of Science, North University of China, Taiyuan 030051, China \\ Correspondence should be addressed to Zhi Cheng; chengzhi@nuc.edu.cn
}

Received 28 February 2018; Revised 4 May 2018; Accepted 20 May 2018; Published 4 July 2018

Academic Editor: Kestutys Baltakys

Copyright (c) 2018 Zhi Cheng et al. This is an open access article distributed under the Creative Commons Attribution License, which permits unrestricted use, distribution, and reproduction in any medium, provided the original work is properly cited.

Circulating fluidized bed combustion (CFBC) desulfurization slag is a waste residue discharged from coal power plants. In this article, expansion characteristics and compressive strength of mortars containing CFBC desulfurization slag were evaluated, subjected to mechanical grinding time, the amount of additive, and chemical activation. Correlations between the linear expansion rate and compressive strength were investigated. The hydration products of cement-slag cementitious system were analyzed by X-ray diffraction (XRD) and scanning electron microscopy (SEM). The results show that mechanical grinding can increase both the expansion and compressive strength of mortars containing CFBC desulfurization slag, and the compressive strength and linear expansion can develop in coordination. While increasing the amount of the fine desulfurization slag, the linear expansion rate increases, and the compressive strength reaches to the maximum when the amount is $30 \%$. Moderate sodium sulfate as an activator can both promote the compressive strength and increase the expansion of mortars.

\section{Introduction}

In 2012, coal accounted for about $30 \%$ of primary energy sources available and played a role in $41 \%$ of the world's electricity generation. As the largest country in terms of coal consumption in the world, China consumed 2.943 billion tons of standard coal equivalent in 2013, accounting for more than half of the global total. It is estimated that global coal consumption will increase by more than $50 \%$, as compared with $97 \%$ in developing countries, by $2030[1,2]$. Circulating fluidized bed combustion (CFBC) technology is an environmentally friendly, efficient, and clean coal-fired technology, which can use common bituminous coal, anthracite, lignite, peat, and coal gangue as fuels [3-6]. CFBC was popularized rapidly in the last two decades. Because limestone is added to CFBC as a desulfurizer, the discharged ash and slag of CFBC are 30\%-40\% more than those of pulverized coal combustion. Most of them cannot be utilized and stacked directly in storage sites, which not only occupied the land and polluted the environment but also wasted. The comprehensive utilization of CFBC ash and slag has aroused much attention.

$\mathrm{CFBC}$ desulfurization slag is the waste residue discharged from the bottom of CFBC [7]. CFBC desulfurized slag is produced at $850 \sim 900^{\circ} \mathrm{C}$, which is different from pulverized coal combustion ashes. The physical and chemical properties of CFBC desulfurization slag are also different from pulverized coal combustion ashes [8,9]. Previous researches have shown that CFBC desulfurization slag has pozzolanic activity, self-hardening property, large water absorption, and high expansibility. A higher content of $\mathrm{CaSO}_{4}$ and $\mathrm{f}-\mathrm{CaO}$ leads to larger volume expansion, which has adverse effects on the properties of products prepared with CFBC desulfurization slag and limits its use in building materials [10].

Some researchers $[9,11,12]$ have performed investigations on the expansion characteristics and mechanical properties of CFBC desulfurized slag. They concluded that the expansibility is closely related to the content of $\mathrm{SO}_{3}$ 
TABLE 1: The chemical composition of CFBC desulfurization slag (wt.\%).

\begin{tabular}{ccccccccccccc}
\hline $\mathrm{SiO}_{2}$ & $\mathrm{Al}_{2} \mathrm{O}_{3}$ & $\mathrm{CaO}$ & $\mathrm{SO}_{3}$ & $\mathrm{Fe}_{2} \mathrm{O}_{3}$ & $\mathrm{MgO}$ & $\mathrm{TiO}_{2}$ & $\mathrm{~K}_{2} \mathrm{O}$ & $\mathrm{P}_{2} \mathrm{O}_{5}$ & $\mathrm{Na}_{2} \mathrm{O}$ & $\mathrm{MnO}$ & $\mathrm{Cl}$ & $\mathrm{ZnO}$ \\
\hline 42.19 & 25.9 & 10.99 & 5.91 & 3.10 & 1.35 & 0.84 & 0.79 & 0.12 & 0.06 & 0.03 & 0.02 & 0.01 \\
\hline
\end{tabular}

(usually anhydrite) and $\mathrm{f}-\mathrm{CaO}$, and mechanical grinding and chemical activation can increase CFBC desulfurized slag's strength. However, CFBC desulfurization slags from different regions or different types of coals have different chemical composition content, which results in significant disparities in activity and expansibility. Mechanical grinding, especially ultrafine grinding, can improve the activity of desulfurization slag, but the influence mechanism of grinding on expansion is not clear. The use of chemical activators such as sulfate and other materials can improve the activity of desulfurization slag but increase volume expansion. The expansion in late hydration may cause the strength to be reduced or even eliminated [13-15]. Moreover, there is seldom report on study of CFBC desulfurization slag in mortar or concrete as an additive. It is necessary to research on desulfurization slag as additive so as to verify the possibility of CFBC desulfurization slag as an additive in mortar or concrete.

In this paper, mortars containing CFBC desulfurization slag were prepared, the linear expansion rate and compressive strength of the mortars were tested, the influence mechanism of grinding time, amount of CFBC desulfurization slag and sodium sulfate on the expansion characteristics, and compressive strength of mortars were investigated, and furthermore, the correlation between the expansion characteristics and compressive strength of the mortar was analyzed.

\section{Experiments}

2.1. Materials and Sample Preparation. Raw CFBC desulfurization slag was from Pingshuo Coal Gangue Power Plant of Shanxi Province in China. It was ground by a standard ball mill for 13 minutes, 25 minutes, 39 minutes, 55 minutes, and 72 minutes, respectively. After grinding, the samples were sent through an $80 \mu \mathrm{m}$ square hole sieve. Samples were labeled as T1, T2, T3, T4, and T5 and then used in this experiment. The physical and chemical properties of CFBC desulfurization slag were determined by an ARL 9800XP plus X-ray fluorescence (XRD), and the results are given in Table 1 and Figure 1.

The specific surface area and particle size distribution of CFBC desulfurized slag under different grinding times were tested using the HELOS-RODOS (Sympatec GmbH Co., Ltd., Clausthal-Zellerfeld, Germany), as shown in Table 2. Differential and cumulative particle size distribution curves are shown in Figure 2. With grinding time increasing, the specific surface area also increases. However, when grinding time is more than 55 minutes and the powder was ground until 72 minutes, the specific surface area decreases. This is due to the "agglomeration" phenomenon [16].

The morphology of raw slag and ground slags was characterized by field emission scanning electron microscopy

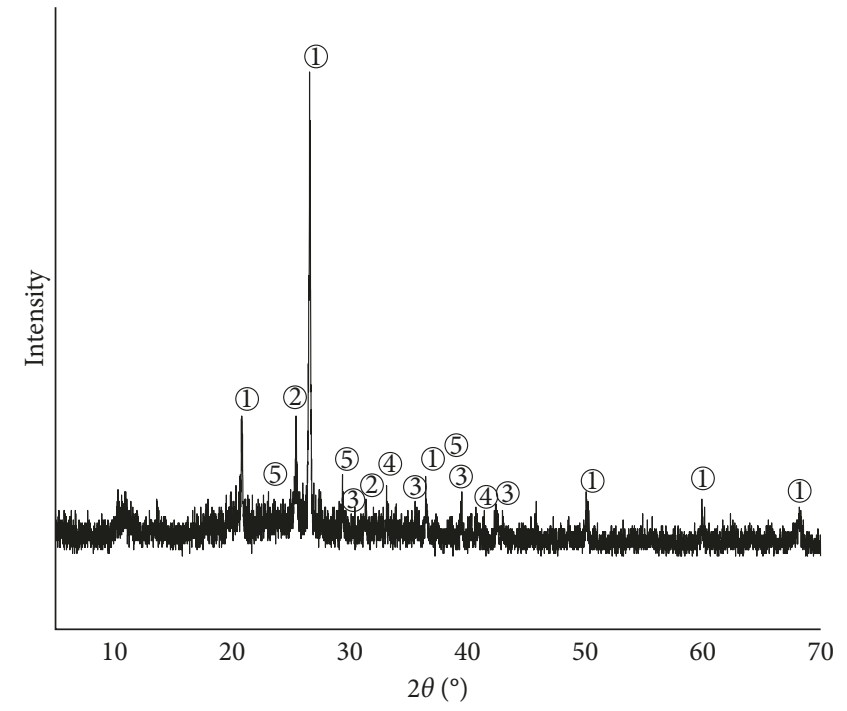

$\begin{array}{ll}\text { (1) Quartz } & \text { (4) Hematite } \\ \text { (2) Anhydrite } & \text { (5) Calcite } \\ \text { (3) } \mathrm{f}-\mathrm{CaO} & \end{array}$

Figure 1: XRD patterns of CFBC desulfurized slag.

(FE-SEM, Hitachi S4800), as shown in Figure 3. Through scanning electron microscopy (SEM) observation, it can be observed that the surface of the raw desulfurization slag is loose and porous. Although the particle size becomes smaller after grinding, the surface is still loose and porous $[15,16]$.

The cement of Grade PO 42.5 from Chihoi cement plant was used in this experiment. The fine aggregate was China ISO Standard sand, produced by Xiamen ISO Standard Sand Co., Ltd. Solid sodium sulfate was produced by Tianjin Guangfu Technology Development Co., Ltd. Polycarboxylate superplasticizer was used as the waterreducing admixture.

2.2. Mixture Proportions of Mortars. The mixture proportions of mortars are shown in Table 3. Cementitious materials included cement and ground CFBC desulfurization slag. The ratio of cementitious materials and standard sand was 1:2 (mass ratio), the water-to-binder ratio (W/B) was 0.3 , and the ground slags were used from T1 to T5. The dosages of ground desulfurization slag were $10 \%, 20 \%, 30 \%, 40 \%$, and $50 \%$ of the total cementitious materials. The dosages of sodium sulfate were $1 \%, 1.5 \%$, and $2 \%$ of the total cementitious materials. Thirteen types of mortars (SJ1 SJ13) were created, referring to JC/T 603-2004, "standard test method for drying shrinkage of mortar."

2.3. Test Methods. The compressive strength of mortars was tested according to the Chinese Standard GBT 17671-1999, 
TABLE 2: Particle size distribution with grinding time of CFBC desulfurization slag.

\begin{tabular}{|c|c|c|c|c|c|c|c|c|c|}
\hline \multirow{2}{*}{$\begin{array}{l}\text { Grinding time } \\
(\min )\end{array}$} & \multirow{2}{*}{$\begin{array}{l}\text { Specific surface area } \\
\qquad\left(\mathrm{m}^{2} / \mathrm{kg}\right)\end{array}$} & \multicolumn{8}{|c|}{ Particle size distribution (\%) } \\
\hline & & $0-3 \mu \mathrm{m}$ & $3-10 \mu \mathrm{m}$ & $10-18 \mu \mathrm{m}$ & $18-25 \mu \mathrm{m}$ & $25-36 \mu \mathrm{m}$ & $36-50 \mu \mathrm{m}$ & $50-102 \mu \mathrm{m}$ & $>102 \mu \mathrm{m}$ \\
\hline 13 & 260 & 13.67 & 12.22 & 9.46 & 5.72 & 7.87 & 8.61 & 23.53 & 18.92 \\
\hline 25 & 330 & 17.49 & 15.79 & 12.17 & 7.18 & 9.91 & 10.68 & 21.52 & 5.26 \\
\hline 39 & 400 & 21.33 & 18.97 & 14.08 & 8.09 & 10.7 & 10.37 & 12.87 & 3.59 \\
\hline 55 & 650 & 32.89 & 22.66 & 13.89 & 8.81 & 9.44 & 7.55 & 4.76 & 0 \\
\hline 72 & 630 & 31.21 & 22.93 & 14.65 & 8.73 & 8.87 & 6.9 & 6.71 & 0 \\
\hline
\end{tabular}

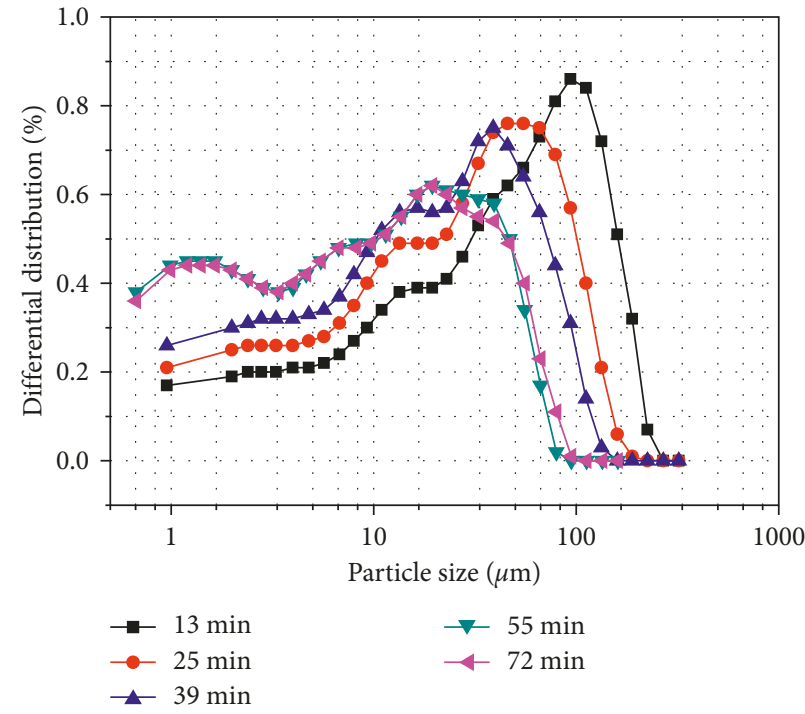

(a)

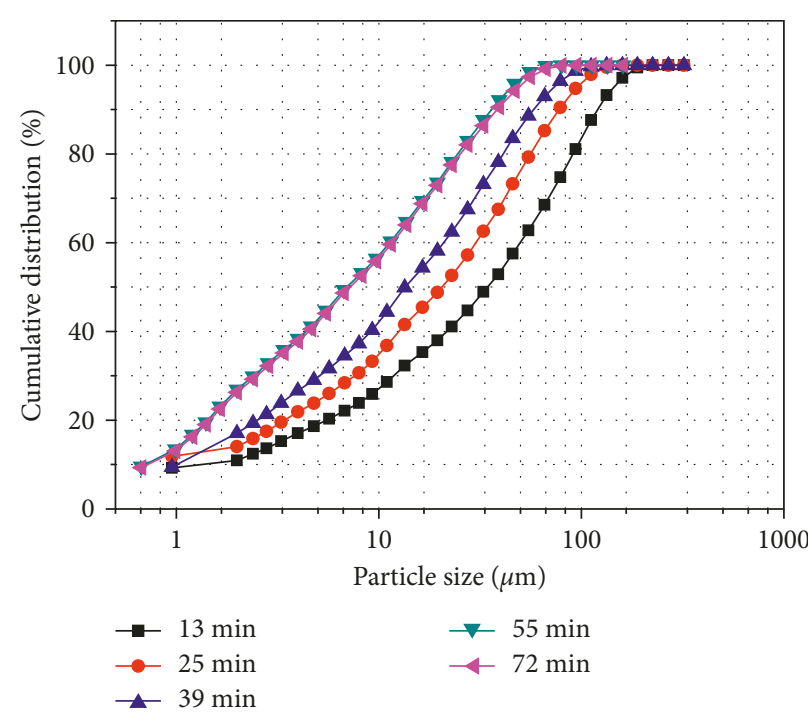

(b)

FIgURe 2: Differential and cumulative particle size distribution of CFBC desulfurization slag.

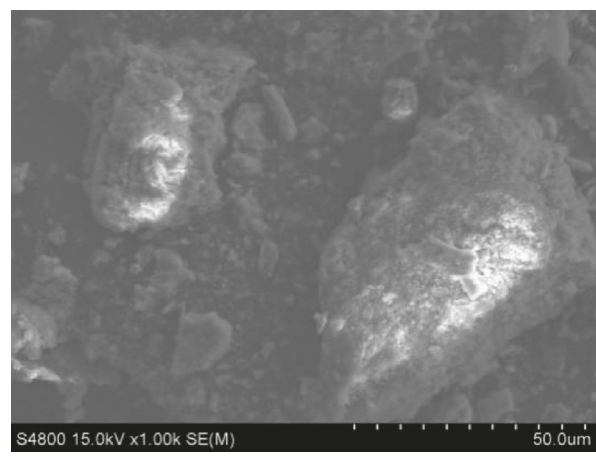

(a)

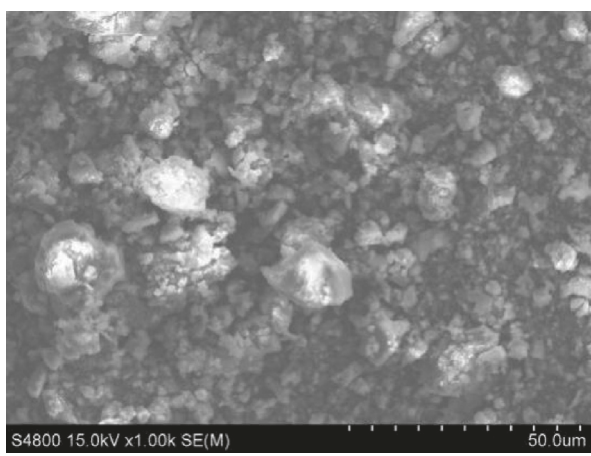

(c)

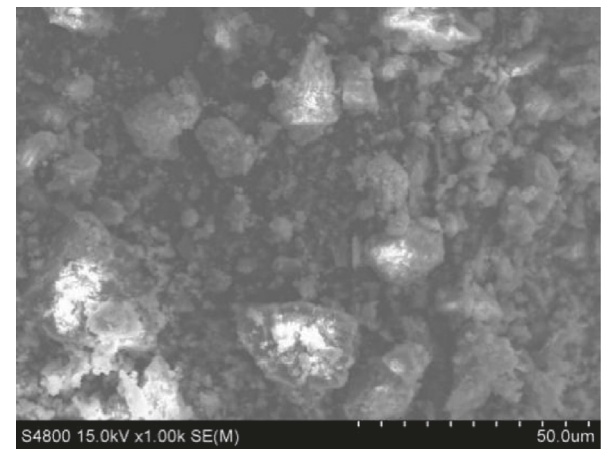

(b)

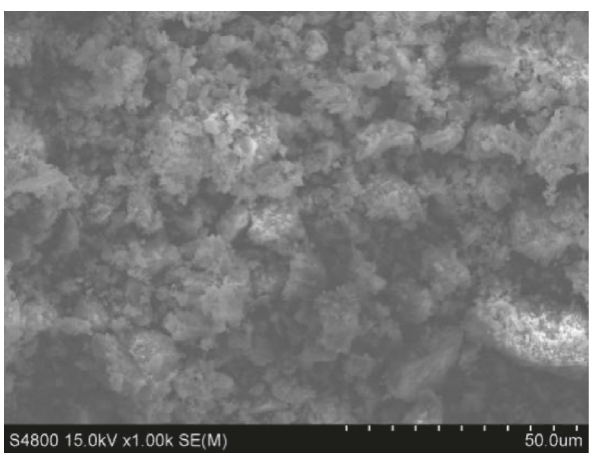

(d)

Figure 3: SEM images of CFBC desulfurization slag particles. (a) Raw slag; (b) T1 (13 min); (c) T3 (39 min); (d) T5 (72 min). 
TABLE 3: Mixture proportions of mortars.

\begin{tabular}{|c|c|c|c|c|c|c|c|c|}
\hline Number & Fineness & $\begin{array}{l}\text { Cementitious } \\
\text { materials }\end{array}$ & Cement & $\begin{array}{l}\text { Desulfurization } \\
\text { slag }\end{array}$ & $\begin{array}{l}\text { Sodium } \\
\text { sulfate }\end{array}$ & $\begin{array}{l}\text { Standard } \\
\text { sand }\end{array}$ & Water & $\begin{array}{l}\text { Water- } \\
\text { reducing } \\
\text { admixtures }\end{array}$ \\
\hline SJ1 & $\mathrm{T} 1(13 \mathrm{~min})$ & 500 & 350 & 150 & 0 & 1000 & 150 & $1.0 \%$ \\
\hline SJ2 & $\mathrm{T} 2(25 \mathrm{~min})$ & 500 & 350 & 150 & 0 & 1000 & 150 & $0.9 \%$ \\
\hline SJ3 & T3 (39 min) & 500 & 350 & 150 & 0 & 1000 & 150 & $1.0 \%$ \\
\hline SJ4 & $\mathrm{T} 4(55 \mathrm{~min})$ & 500 & 350 & 150 & 0 & 1000 & 150 & $0.9 \%$ \\
\hline SJ5 & T5 (72 min $)$ & 500 & 350 & 150 & 0 & 1000 & 150 & $0.8 \%$ \\
\hline SJ6 & - & 500 & 500 & 0 & 0 & 1000 & 150 & $0.5 \%$ \\
\hline SJ7 & T3 (39 min) & 500 & 450 & 50 & 0 & 1000 & 150 & $0.8 \%$ \\
\hline SJ8 & T3 (39 min) & 500 & 400 & 100 & 0 & 1000 & 150 & $0.8 \%$ \\
\hline SJ9 & T3 $(39 \mathrm{~min})$ & 500 & 300 & 200 & 0 & 1000 & 150 & $1.1 \%$ \\
\hline SJ10 & T3 (39 min) & 500 & 250 & 250 & 0 & 1000 & 150 & $1.2 \%$ \\
\hline SJ11 & $\mathrm{T} 3(39 \mathrm{~min})$ & 500 & 350 & 150 & 5 & 1000 & 150 & $1.2 \%$ \\
\hline SJ12 & T3 (39 min) & 500 & 350 & 150 & 7.5 & 1000 & 150 & $1.4 \%$ \\
\hline SJ13 & $\mathrm{T} 3(39 \mathrm{~min})$ & 500 & 350 & 150 & 10 & 1000 & 150 & $1.6 \%$ \\
\hline
\end{tabular}

"inspection method for the strength of the cement sand mortar (ISO method)." The specimens were put in a standard curing box after pouring. The mold was removed after 24 hours and then cured in water.

The linear expansion rate test was carried out according to the Chinese Industry Standard JC/T 603-2004, "standard test method for drying shrinkage of mortar." The curing condition was same as compressive strength specimens'. After demoulding, the initial length values of specimens were measured as $L_{0}$, and the length values at any age were measured as $L_{1}$. The expression $\left(L_{1}-L_{0}\right) / L_{0} \times 100 \%$ can be used to calculate the linear expansion rate of mortar at each age.

Mineralogical compositions and the hydrated products were identified via X-ray diffraction (XRD) using the D/max-RB X-ray diffraction system (Japan Rigaku Corporation, Tokyo, Japan). The microstructures of the hydrated products were detected using SEM (Hitachi S4800; Hitachi, Ltd., Tokyo, Japan).

\section{Results and Discussion}

3.1. Influences of Grinding Time on Mortars. Linear expansion rate curves of the mortars with different grinding times are shown in Figure 4. The linear expansion rate of the mortars has a large fluctuation in the early age. After removal of the mold, there is a period of controlled expansion or shrinkage from the first 7 days to 14 days. After 14 days, the mortars continue to expand or shrink and become stable after 28 days. SP1 shows shrinkage characteristics, while SP2, SP3, SP4, and SP5 show expansion characteristics. The longer the slag's grinding time, the bigger the mortar's linear expansion rate.

The existence of anhydrite and $\mathrm{f}-\mathrm{CaO}$ in desulfurization slag is the main reason why mortars expand. In contact with water, anhydrite produces gypsum and $\mathrm{f}-\mathrm{CaO}$ produces $\mathrm{Ca}$ $(\mathrm{OH})_{2}$, and then, hydration products continue to react to form ettringite. These reactions all lead to volume expansion [17-19]. In desulfurization slag, the anhydrite is wrapped by $\mathrm{f}-\mathrm{CaO}$. On the one hand, grinding can increase the

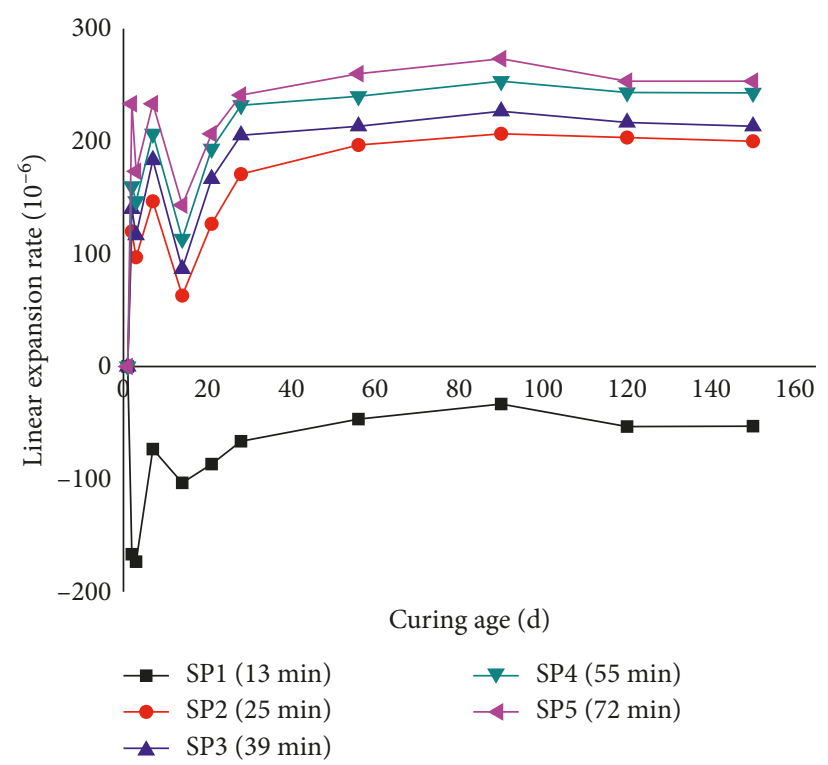

FIgURE 4: Linear expansion rate of the mortars with different grinding times.

content of $\mathrm{f}-\mathrm{CaO}$ and improve the alkalinity, which will help to produce $\mathrm{Ca}(\mathrm{OH})_{2}$ and accelerate the hydration of the anhydrite; on the other hand, grinding can destruct the wrapping structure and release anhydrite, which will help to produce gypsum. The longer the grinding time is, the more the anhydrite and $\mathrm{f}-\mathrm{CaO}$ will be. Therefore, the larger the linear expansion rate will be.

The compressive strengths of mortars with different grinding times are shown in Figure 5. While curing age increases, the compressive strengths of mortars containing desulfurization slag with various grinding times all increase. At each age, the longer the grinding time is, the bigger the compressive strength will be.

The hydration products of desulfurization slag mainly are calcium silicate hydrate $(\mathrm{C}-\mathrm{S}-\mathrm{H})$ gel, hydrated calcium aluminate, gypsum, calcium hydroxide, ettringite, etc. Among them, C-S-H gel and ettringite are the main 


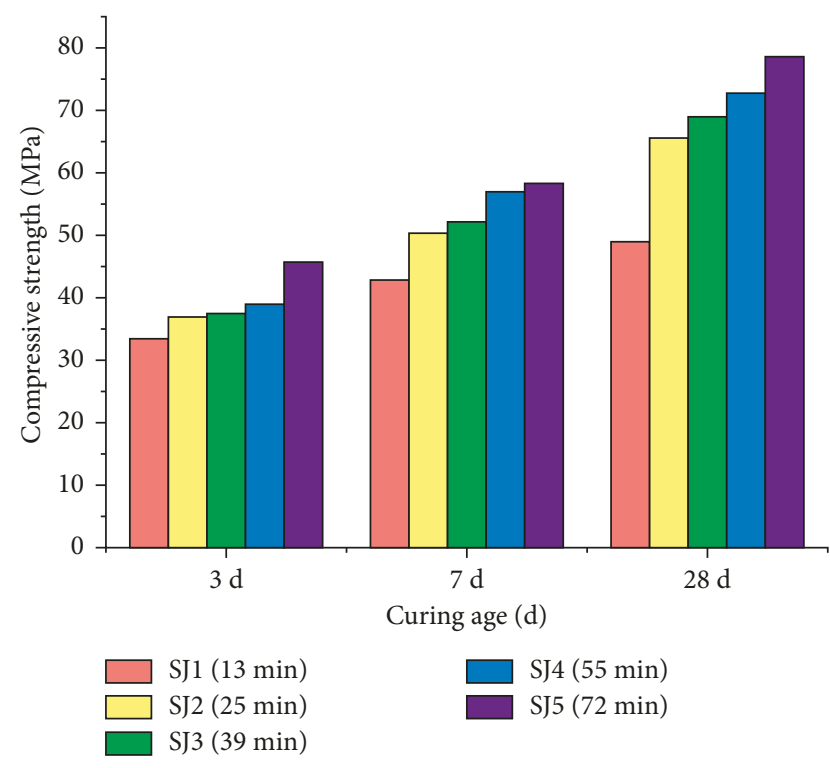

FIgURE 5: Compressive strength of the mortars with different grinding times.

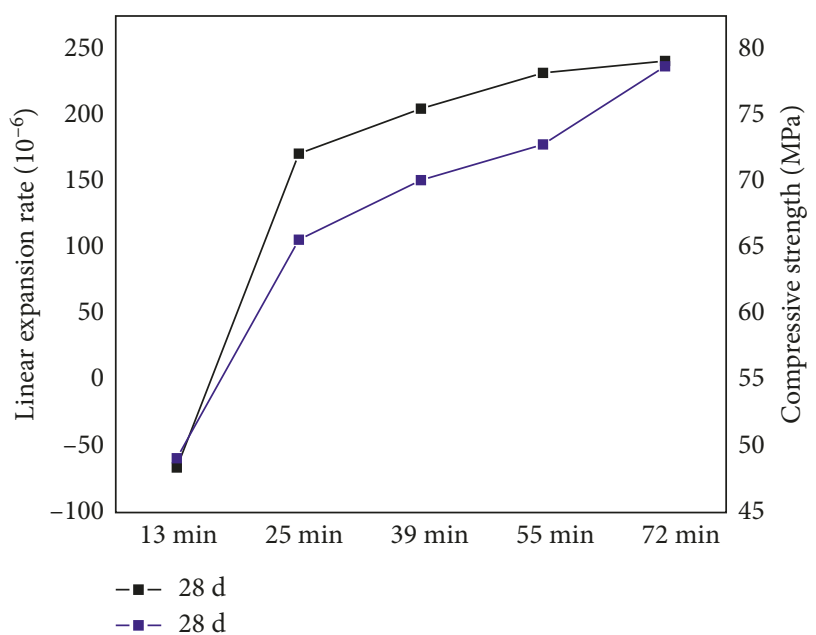

Figure 6: Correlation between the linear expansion rate and compressive strength.

materials forming cementitious system strength. Grinding can increase the surface area of the desulfurization slag, improve the activity of active components such as $\mathrm{SiO}_{2}$ and $\mathrm{Al}_{2} \mathrm{O}_{3}$, and make the hydration process fast [20]. The longer the grinding time is, the quicker and better the hydration will be, and the more the $\mathrm{C}-\mathrm{S}-\mathrm{H}$ gel and ettringite will produce. Meanwhile, the hydration of anhydrite is also faster, which can fill the voids and improve strength.

The correlation curve of linear expansion rate and compressive strength under different grinding times of desulfurization slag at $28 \mathrm{~d}$ age is shown in Figure 6. The linear expansion rate and compressive strength of mortars all increase while grinding time increases. So we can conclude that the linear expansion rate is positively correlated with the compressive strength under different grinding times. This indicates that mechanical grinding can improve both

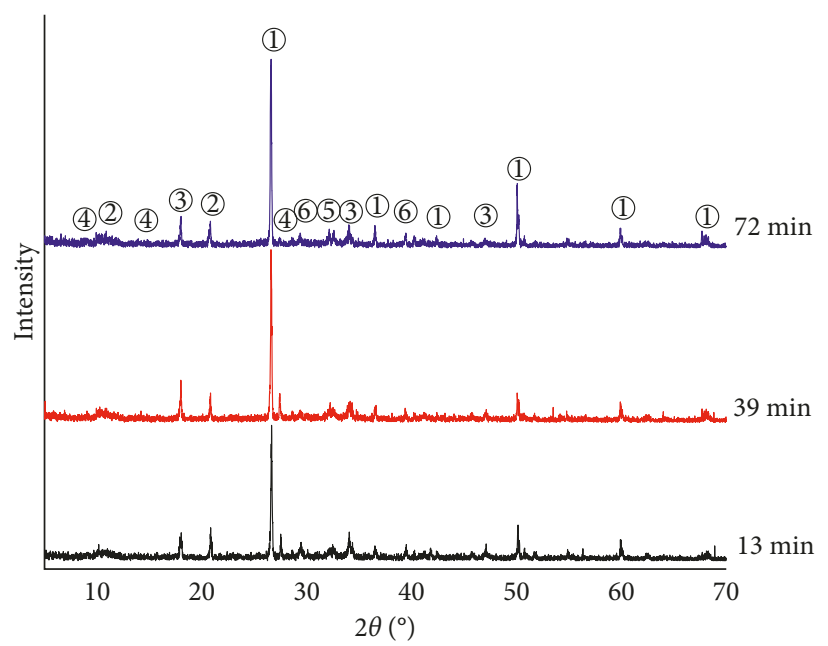
(1) Quartz
(2) Gypsum
(4) Ettringite
(3) Portlandite
(5) $\mathrm{C}_{3} \mathrm{~S}$
(6) Calcite

FIGURE 7: XRD patterns of the mortars with different grinding times at $3 \mathrm{~d}$ age.

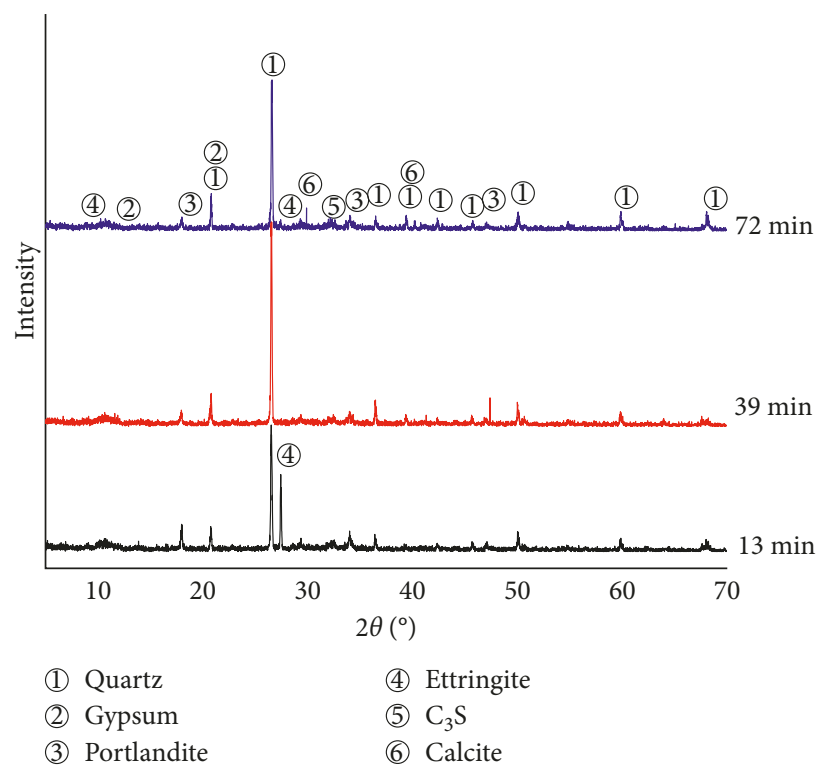

FIGURE 8: XRD patterns of the mortars with different grinding times at $28 \mathrm{~d}$ age.

the linear expansion rate and the compressive strength of the mortars, and the compressive strength and linear expansion can develop in coordination.

XRD patterns of the mortars with different grinding times at different ages are shown in Figures 7 and 8. We can find that, as grinding time increases, $\mathrm{X}$-ray diffraction peak intensity of $\mathrm{Ca}(\mathrm{OH})_{2}$ and gypsum has little difference at $3 \mathrm{~d}$ age, while X-ray diffraction peak intensity of $\mathrm{Ca}(\mathrm{OH})_{2}$ decreases, and X-ray diffraction peak intensity of gypsum increases at $28 \mathrm{~d}$ age. This indicates that the longer the grinding time is, the faster and greater the $\mathrm{Ca}(\mathrm{OH})_{2}$ reacts with other substances, and the more the anhydrite hydrates, 


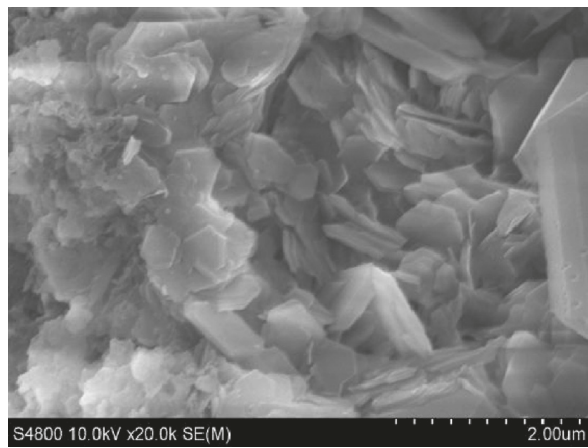

(a)

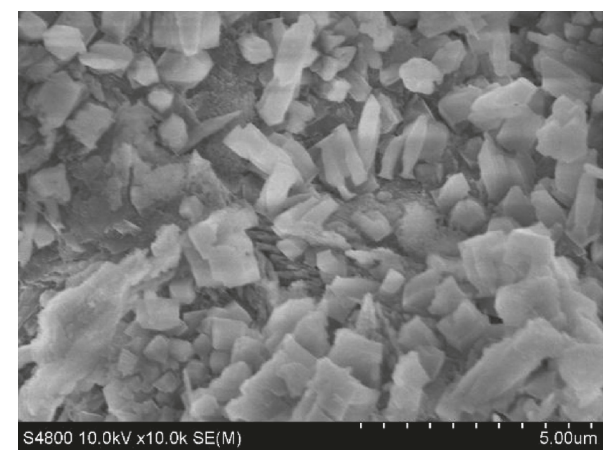

(b)

Figure 9: SEM of mortars with different grinding times at $28 \mathrm{~d}$ age. (a) SJ1; (b) SJ5; $\mathrm{Ca}(\mathrm{OH})_{2}$ is hexagonal plate; gypsum is clavate.

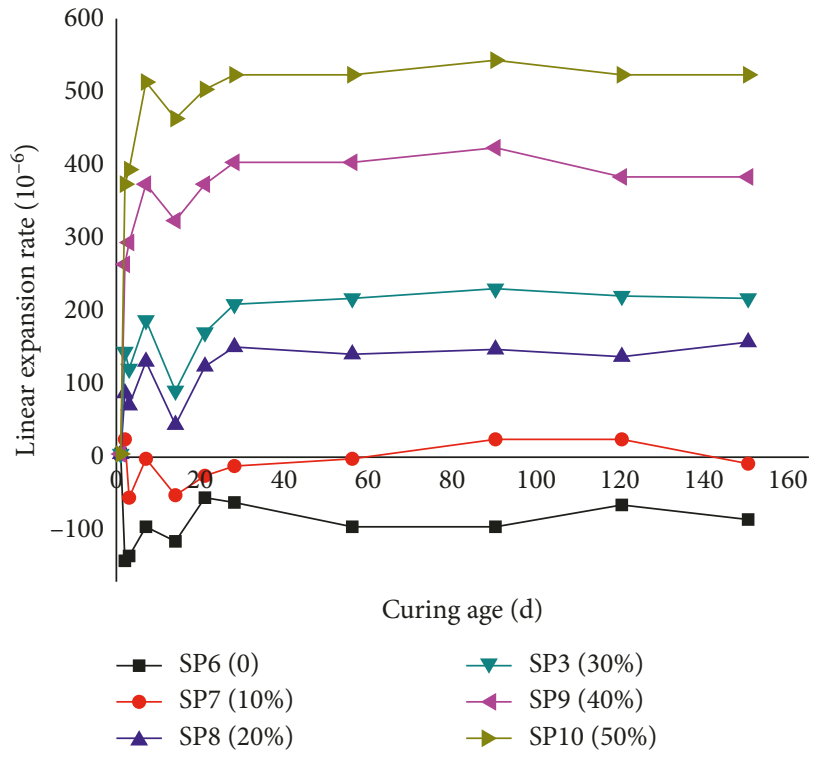

Figure 10: Linear expansion rate of mortars with different amounts of slag.

and then, the more the $\mathrm{C}-\mathrm{S}-\mathrm{H}$ gel and ettringite produce. This is the reason why longer grinding time of desulfurization slag leads to larger volume expansion and bigger compressive strength. By SEM, we can find that there is a large amount of hexagonal plate $\mathrm{Ca}(\mathrm{OH})_{2}$ in $\mathrm{SJ} 1$ and a large amount of clavate gypsum in SJ5 at $28 \mathrm{~d}$ age, as shown in Figure 9.

\subsection{Influences of Desulfurization Slag's Amount on Mortars.} As shown in Figure 10, comparing with SJ6, SJ1 SJ5 containing fine desulfurization slag show clear expansion characteristics. The specimens release expansion intensively for 7 days, then shrink from 7 days to 14 days, and after that, continue to expand and essentially stabilize after 28 days. The linear expansion rate is closely related to the amount of the fine desulfurization slag. The linear expansion rate increases with the amount of the fine desulfurization slag, which shows a positive correlation. That is because that the larger the amount of fine desulfurization slag, the more the

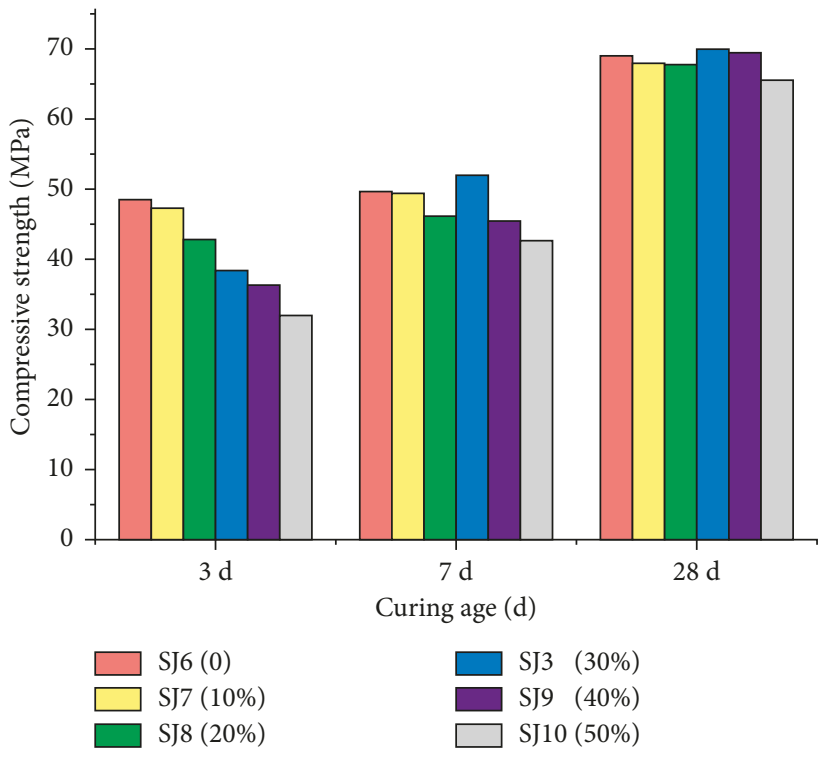

FIgURE 11: Compressive strength of mortars with different amounts of slag.

expansion component such as anhydrite and $\mathrm{f}-\mathrm{CaO}$, and then the larger the expansion rate.

It can be seen from Figure 11 that all the compressive strengths of SJ1 SJ5 at $3 \mathrm{~d}$ age decrease when fine desulfurization slag is added. The bigger the amount of fine desulfurization slag, the bigger the decline. At $7 \mathrm{~d}$ age, the compressive strength of SJ3 with the content of $30 \%$ is higher than that of SJ6. The compressive strengths of SJ9 and SJ10 also increase significantly, which reduce the gap with SJ6. At $28 \mathrm{~d}$ age, SJ 3 gains the highest compressive strength, SJ9 also gains higher compression strength than SJ6, and SJ10 has the lowest compressive strength but is down by only $4.8 \%$ in comparison with SJ6. The results indicate that the fine desulfurization slag has a negative effect on the early strengths of the mortars. The greater adverse effect occurs with a greater amount of additive. Meanwhile, the fine desulfurization slag can promote the growth speed of the mortars' compressive strength in later stage, and the compressive strength can be raised by a reasonable amount of fine desulfurization slag. 


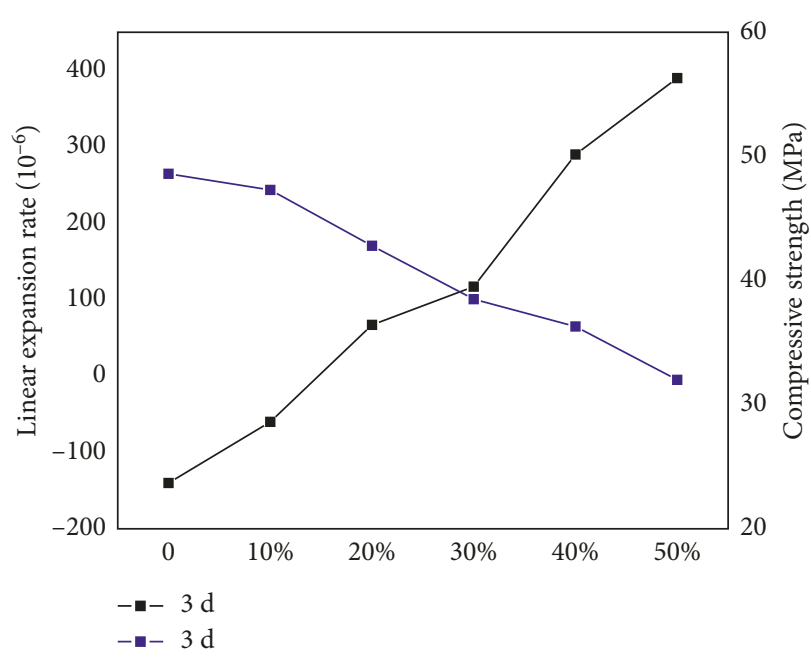

(a)

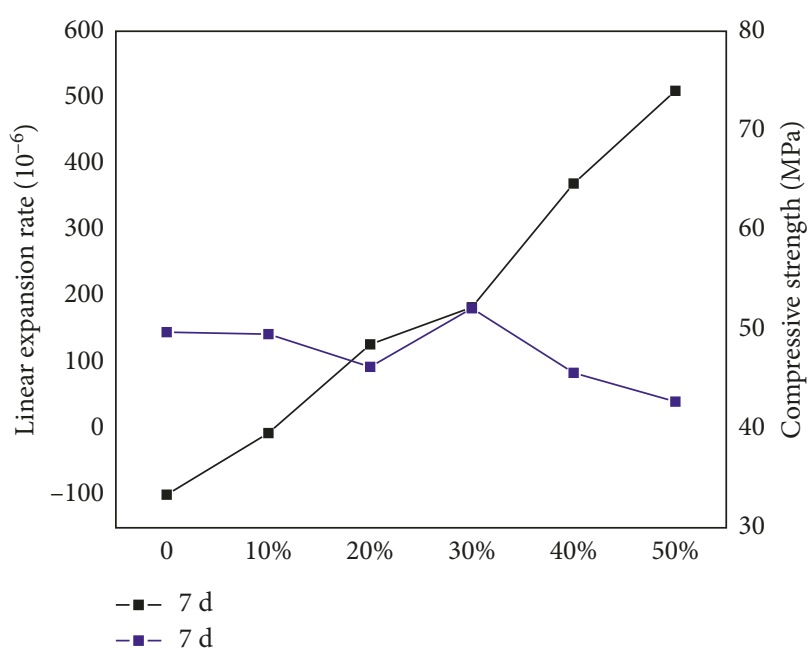

(b)

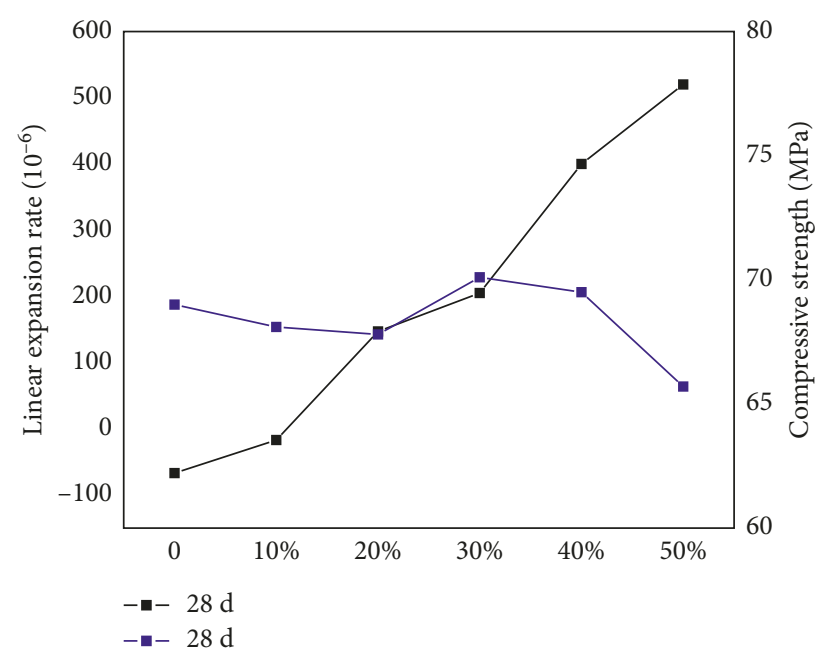

(c)

FIGURE 12: Correlation between the linear expansion rate and compressive strength.

The fine desulfurization slag contains active compositions such as $\mathrm{SiO}_{2}, \mathrm{Al}_{2} \mathrm{O}_{3}$, and $\mathrm{CaO}$. The activity has been further improved after mechanical grinding [21], so the slag has good activity. But the fine desulfurization slag also contains anhydrite, which hydrates slowly in the early age. So its hydration and hardening are slower than those of cement in the early age [22-24]. Therefore, in the early age, the higher the amount of fine desulfurization slag, the lower the activity, the slower the hardening speed, and the lower the strength. While curing age continues to increase, more anhydrite hydrates and more gypsum is produced. Gypsum can continue to react with $\mathrm{Ca}(\mathrm{OH})_{2}$ and hydrated calcium aluminate and then produce ettringite. The ettringite can fill the pores and improve the compactness of mortars [25], so the compressive strength increases rapidly. But too much fine desulfurization slag can lead to great expansion and anhydrite cannot hydrate completely, which decrease the compressive strength of the mortar. So there exists a reasonable amount of fine desulfurization slag. When the amount is $30 \%$, the compressive strengths at $7 \mathrm{~d}$ age and $28 \mathrm{~d}$ age gain the maximum compressive strength.

As shown in Figure 12, at $3 \mathrm{~d}$ age, with the increase of the desulfurization slag's amount, the linear expansion rate of the mortars increases gradually, while the compressive strength of the mortars decreases. The linear expansion rate and the compressive strength are negatively correlated. At the age of $7 \mathrm{~d}$ and $28 \mathrm{~d}$, with an increase of desulfurization slag's amount, the linear expansion rate increases gradually, but the compressive strength gradually increases only when the amount is $20 \% \sim 30 \%$. It indicates that expansion and compressive strength of the mortars develop in coordination only when the amount is $20 \% \sim 30 \%$. When the amount is $30 \%$, the compressive strength reaches to the maximum.

As shown in Figure 13, at $3 \mathrm{~d}$ age, the diffraction peak intensity of gypsum increases with the increase of amount, while $\mathrm{Ca}(\mathrm{OH})_{2}$ is not very different. This indicates that, in the early age, the higher the amount of the desulfurization slag, the more the dissolved anhydrite, and the more the gypsum. The $\mathrm{Ca}(\mathrm{OH})_{2}$ generated by calcium oxide and the 


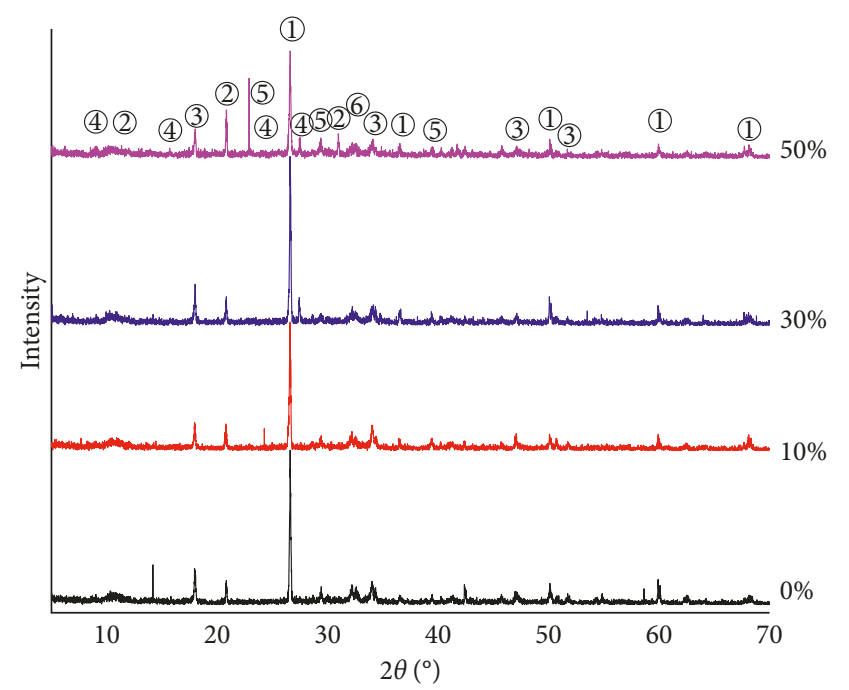
(1) Quartz low
(2) Gypsum
(3) Portlandite
(4) Ettringite
(5) Calcite
(6) $\mathrm{C}_{3} \mathrm{~S}$

FIGURE 13: XRD patterns of mortars with different amounts at $3 \mathrm{~d}$ age.

$\mathrm{Ca}(\mathrm{OH})_{2}$ participated in hydration reaction are nearly equal in number. As shown in Figure 14, at $28 \mathrm{~d}$ age, with the increase of the amount, the diffraction peak intensity of the $\mathrm{Ca}(\mathrm{OH})_{2}$ is smaller and smaller, while the diffraction peak intensity of the gypsum is bigger and bigger. This indicates that the higher the amount is, the more the $\mathrm{Ca}(\mathrm{OH})_{2}$ was consumed and the more the anhydrite hydrated to gypsum, which means that the more the $\mathrm{C}-\mathrm{S}-\mathrm{H}$ and ettringite produce.

When the amount of the desulfurization slag is too much, anhydrite cannot hydrate entirely. As shown in Figure 15, a large number of blocky anhydrite can be found, which means that there still exists unhydrated anhydrite. Figure 15 also shows that no cracks exist in SJ10, indicating that expansion did not cause damage to the specimen.

3.3. Influences of Sodium Sulfate on Mortars. As shown in Figure 16, the linear expansion rate of SP11, SP12, and SP13 is larger than that of SP3. The larger the amount of sodium sulfate, the larger the linear expansion rate. This indicates that sodium sulfate can increase the expansion of mortars. As seen from Figure 17, sodium sulfate can also increase the compressive strengths of mortars, especially the early compressive strength. As shown in Figure 18, with an increase in the amount of sodium sulfate, the linear expansion rate and the compressive strength both increase, which means that the linear expansion rate and compressive strength were positively correlated under different amounts of sodium sulfate. We can conclude that the linear expansion and compressive strength can develop in coordination with the addition of sodium sulfate.

The desulfurization slag contains $\mathrm{SO}_{3}$ in a form of anhydrite, and anhydrite hydrates very slowly [26-29]. Researches have shown that alkali and sulfate can improve the

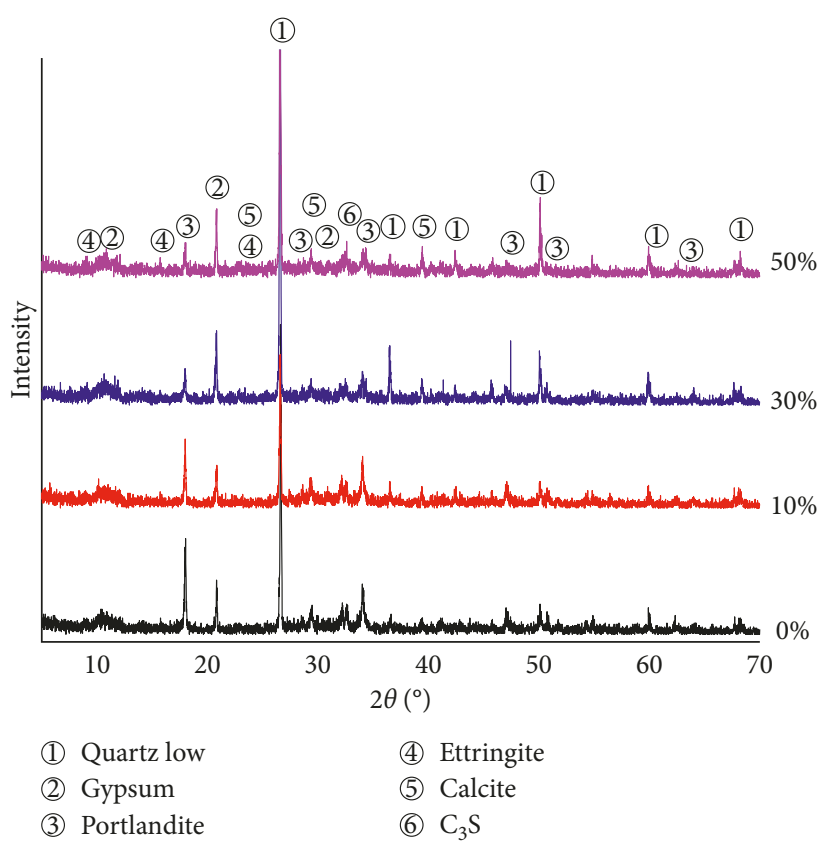

FIGURE 14: XRD patterns of mortars with different amounts at $28 \mathrm{~d}$ age.

activity of modified desulfurization ash [30, 31]. In this work, we used sodium sulfate as an activator.

Previous research has shown that moderate sodium sulfate can improve the early hydration rate of the anhydrite and increase its set and hardening speed greatly, but it has little effect on the later stage [32]. Anhydrite hydrates to gypsum, and then to produce ettringite, all can lead to volume expansion. So the linear expansion rate of mortar increases. Sodium sulfate can also raise the early compressive strength of mortar because of the production of more ettringite.

As shown in Figures 19 and 20, comparing with the mortar without sodium sulfate, the diffraction intensity of $\mathrm{Ca}$ $(\mathrm{OH})_{2}$ and gypsum is weaker, while the diffraction intensity of ettringite is stronger in the mortar with $1.5 \%$ sodium sulfate. This indicates that the hydration consumed more $\mathrm{Ca}(\mathrm{OH})_{2}$ and gypsum and produced more ettringite. Therefore, the compressive strength and expansion rate of mortars are both raised. Through SEM as shown in Figure 21, a large number of clavate gypsum and acicular ettringite were found in the mortar with $1.5 \%$ sodium sulfate at $3 \mathrm{~d}$ age.

\section{Conclusions}

In this work, a series of mortars containing ground desulfurization slag from circulating fluidized bed combustion were prepared. Linear expansion rate and compressive strength were tested to evaluate expansion characteristics and mechanical property. XRD and SEM were used to verify mechanism analysis along with linear expansion rate and compressive strength tests. Several conclusions can be drawn based on the investigation; they are as follows:

Mechanical grinding can improve both the linear expansion rate and the compressive strength of the mortars. The longer the grinding time is, the bigger the linear 


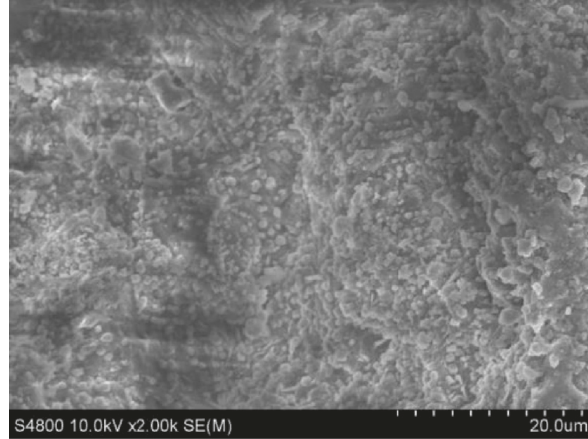

(a)

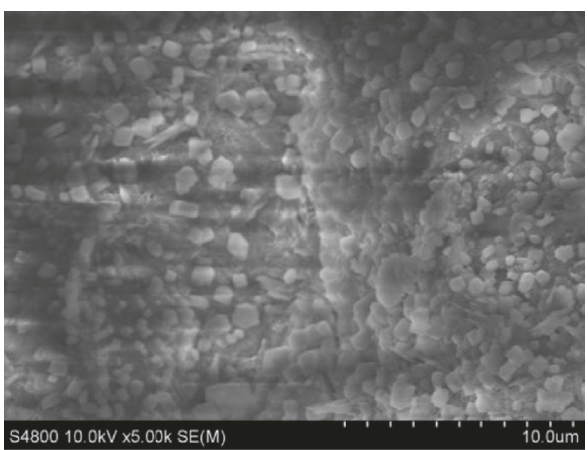

(b)

Figure 15: SEM of SJ10 (50\%). Note: anhydrite is blocky.

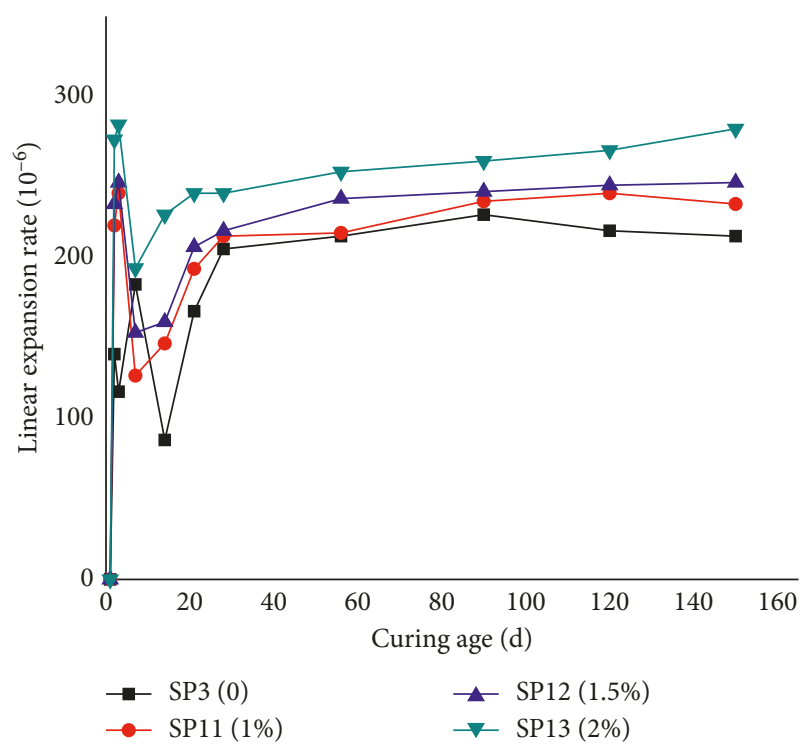

FIGURE 16: Linear expansion rate of mortars with different amounts of sodium sulfate.

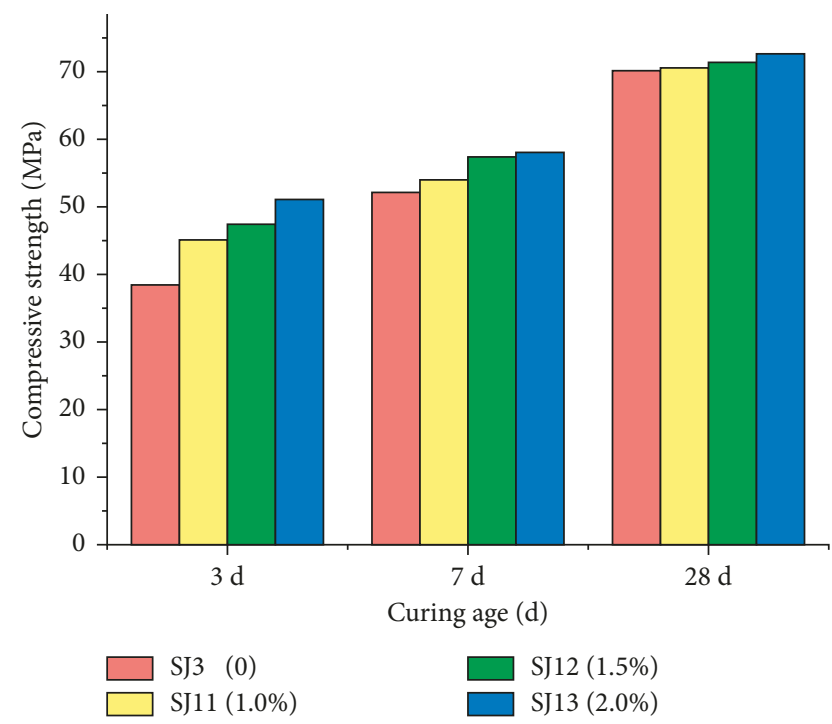

FIgURE 17: Compressive strength of mortars with different amounts of sodium sulfate.

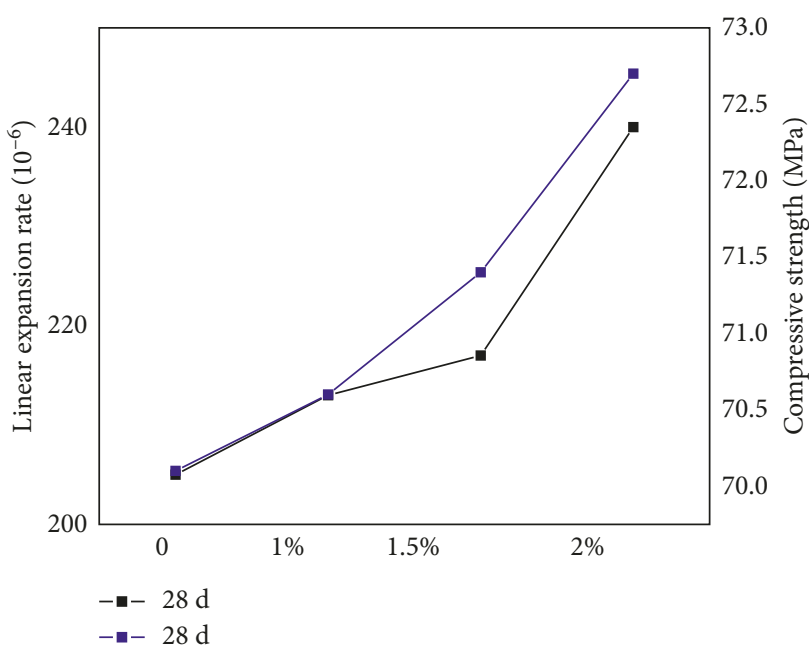

Figure 18: Correlation between the linear expansion rate and compressive strength.

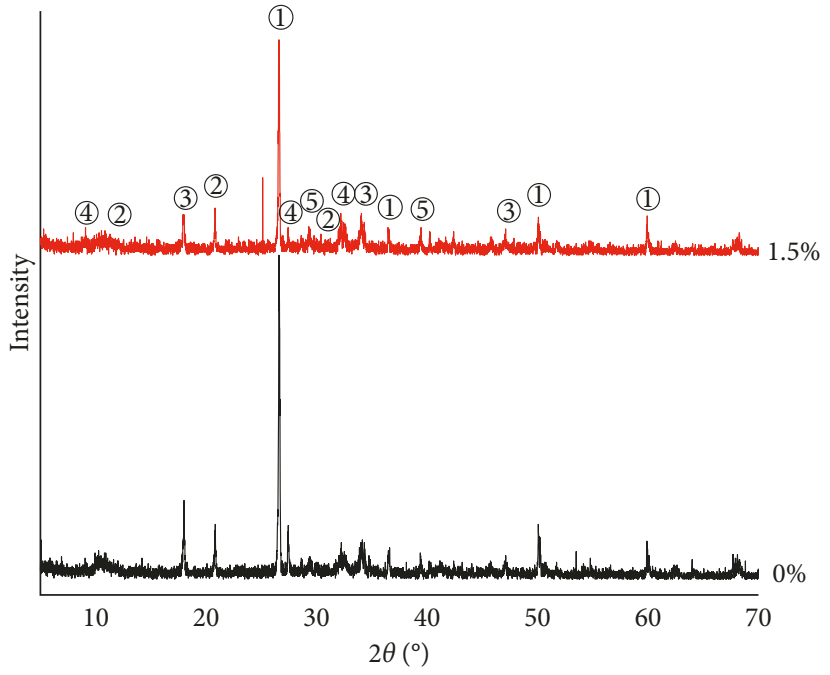
(1) Quartz
(4) Ettringite
(2) Gypsum
(5) Calcite
(3) Portlandite

FIGURE 19: XRD patterns of mortars with different amounts of sodium sulfate at $3 \mathrm{~d}$ age. 


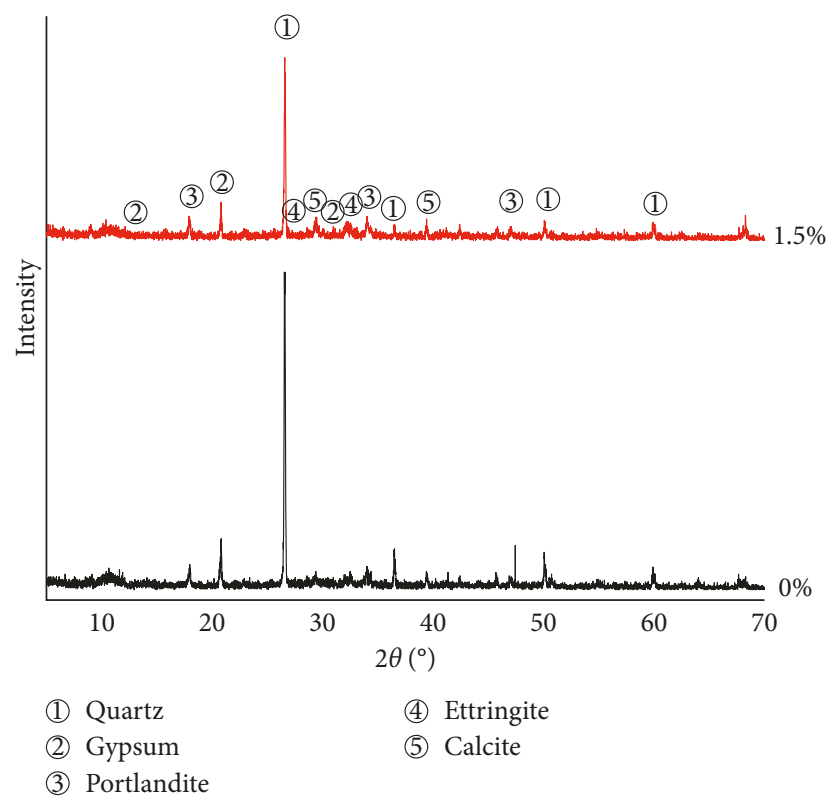

FIGURE 20: XRD patterns of mortars with different amounts of sodium sulfate at $28 \mathrm{~d}$ age.

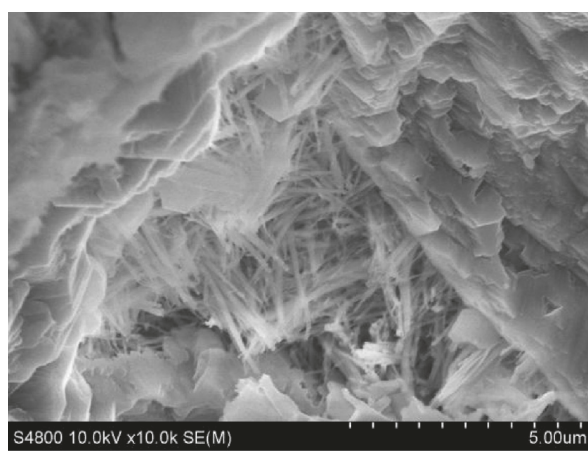

(a)

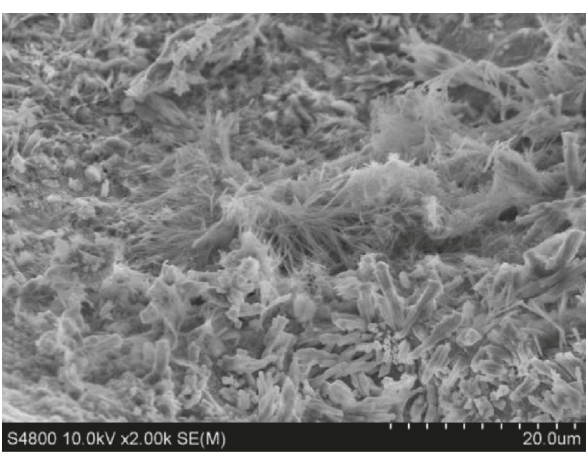

(b)

FIgURE 21: SEM of the mortar (SJ12). Note: AFt is acicular; gypsum is clavate.

expansion rate and the compressive strength are. The linear expansion rate is positively correlated with the compressive strength under different grinding times.

The linear expansion rate increases with the amount of the fine desulfurization slag. At $3 \mathrm{~d}$ age, all the compressive strengths of SJ1 SJ5 added fine desulfurization slag decline. The linear expansion rate and the compressive strength are negatively correlated. At $28 \mathrm{~d}$ age, the compressive strength gradually increases only when the amount is $20 \% \sim 30 \%$, and the mortar with $30 \%$ amount gains the highest compressive strength. There exists a reasonable amount of fine desulfurization slag for the compressive strength of mortar.

Sodium sulfate has an active excitation effect on the hydration of anhydrite in desulfurization slag with a moderate amount, which can promote the compressive strength and increase the expansion of mortars. With an increase in the amount of sodium sulfate, the linear expansion rate and the compressive strength both increase, and they showed a positive correlation.

\section{Data Availability}

The data used to support the findings of this study are available from the corresponding author upon request.

\section{Conflicts of Interest}

The authors declare that they have no conflicts of interest.

\section{Acknowledgments}

This work was financially supported by the Graduate Student Education Innovation Projects of Shanxi Province (no. 2016163) and Science Fundamental Research Projects of Shanxi Province (no. 201601D202048).

\section{Supplementary Materials}

The supplementary materials include images (Figure S1) of the linear expansion rate and compressive strength tests, as 
well as the raw data of the compressive strength (Table S1) and the linear expansion rate (Table S2) of mortars. (Supplementary Materials)

\section{References}

[1] S. Naganathan, A. Yousef Omer Mohamed, and K. Mustapha, "Performance of bricks made using fly ash and bottom ash," Construction and Building Materials, vol. 96, pp. 576-580, 2015.

[2] J. Yuan, "The future of coal in China," Resources, Conservation and Recycling, vol. 129, pp. 290-292, 2018.

[3] J. Zhao, D. Wang, and S. Liao, "Effect of mechanical grinding on physical and chemical characteristics of circulating fluidized bed fly ash from coal Gangue power plant," Construction and Building Materials, vol. 101, pp. 851-860, 2015.

[4] S. Bae and K. Lee, "Carbonation behavior of fly ash with circulating fluidized bed combustion (CFBC)," Journal of the Korean Ceramic Society, vol. 52, no. 2, pp. 154-158, 2015.

[5] H. Nguyen, T. Chang, J. Shih, C. Chen, and T. Nguyen, "Influence of circulating fluidized bed combustion (CFBC) fly ash on properties of modified high volume low calcium fly ash (HVFA) cement paste," Construction and Building Materials, vol. 91, pp. 208-215, 2015.

[6] T. Wu, M. Chi, and R. Huang, "Characteristics of CFBC fly ash and properties of cement-based composites with CFBC fly ash and coal-fired fly ash," Construction and Building $\mathrm{Ma}$ terials, vol. 66, pp. 172-180, 2014.

[7] J. Koornneef, M. Junginger, and A. Faaij, "Development of fluidized bed combustion-an overview of trends, performance and cost," Progress in Energy and Combustion Science, vol. 33, no. 1, pp. 19-55, 2007.

[8] S. Rajaram, "Next generation CFBC," Chemical Engineering Science, vol. 54, no. 22, pp. 5565-5571, 1999.

[9] X. Li, Q. Chen, K. Huang, B. Ma, and B. Wu, "Cementitious properties and hydration mechanism of circulating fluidized bed combustion (CFBC) desulfurization ashes," Construction and Building Materials, vol. 36, pp. 182-187, 2012.

[10] W. Kuo, H. Wang, and C. Shu, "Engineering properties of cementless concrete produced from GGBFS and recycled desulfurization slag," Construction and Building Materials, vol. 63, pp. 189-196, 2014.

[11] Y. Chen, M. Ko, J. Chang, and C. Lin, "Recycling of desulfurization slag for the production of autoclaved aerated concrete," Construction and Building Materials, vol. 158, pp. 132-140, 2018.

[12] N. Dung, T. Chang, and C. Chen, "Engineering and sulfate resistance properties of slag-CFBC fly ash paste and mortar," Construction and Building Materials, vol. 63, pp. 40-48, 2014.

[13] X. Fu, Q. Li, J. Zhai, G. Sheng, and F. Li, "The physicalchemical characterization of mechanically-treated CFBC fly ash," Cement and Concrete Composites, vol. 30, no. 3, pp. 220-226, 2008.

[14] M. Chi and R. Huang, "Effect of circulating fluidized bed combustion ash on the properties of roller compacted concrete," Cement and Concrete Composites, vol. 45, pp. 148-156, 2014.

[15] X. Li, Q. Chen, B. Ma, J. Huang, S. Jian, and B. Wu, "Utilization of modified CFBC desulfurization ash as an admixture in blended cements: physico-mechanical and hydration characteristics," Fuel, vol. 102, pp. 674-680, 2012.

[16] Y. Xia, Y. Yan, and Z. Hu, "Utilization of circulating fluidized bed fly ash in preparing non-autoclaved aerated concrete production," Construction and Building Materials, vol. 47, pp. 1461-1467, 2013.

[17] E. J. Anthony and D. L. Granatstein, "Sulfation phenomena in fluidized bed combustion systems," Progress in Energy and Combustion Science, vol. 27, no. 2, pp. 215-236, 2001.

[18] E. Anthony, L. Jia, and Y. Wu, "CFBC ash hydration studies," Fuel, vol. 84, no. 11, pp. 1393-1397, 2005.

[19] E. J. Anthony, E. M. Bulewicz, K. Dudek, and A. Kozak, "The long term behaviour of CFBC ash-water systems," Waste Management, vol. 22, no. 1, pp. 99-111, 2002.

[20] P. Pourghahramani and E. Forssberg, "Microstructure characterization of mechanically activated hematite using XRD line broadening," International Journal of Mineral Processing, vol. 79, no. 2, pp. 106-119, 2006.

[21] Z. Zhang, J. Qian, C. You, and C. Hu, "Use of circulating fluidized bed combustion fly ash and slag in autoclaved brick," Construction and Building Materials, vol. 35, pp. 109-116, 2012.

[22] C. Freidin, "Influence of variability of oil shale fly ash on compressive strength of cementless building compounds," Construction and Building Materials, vol. 19, no. 2, pp. 127133, 2005.

[23] L. Junfu, Z. Jiansheng, Z. Hai, L. Qing, and Y. Guangxi, "Performance evaluation of a 220t/H CFB boiler with watercooled square cyclones," Fuel Processing Technology, vol. 88, no. 2, pp. 129-135, 2007.

[24] G. Sheng, J. Zhai, Q. Li, and F. Li, "Utilization of fly ash coming from a CFBC boiler co-firing coal and petroleum coke in Portland cement," Fuel, vol. 86, no. 16, pp. 2625-2631, 2007.

[25] G. Sheng, Q. Li, J. Zhai, and F. Li, "Self-cementitious properties of fly ashes from CFBC boilers co-firing coal and highsulphur petroleum coke," Cement and Concrete Research, vol. 37, no. 6, pp. 871-876, 2007.

[26] N. Menad, J. N. Ayala, F. Garcia-Carcedo, E. Ruiz-Ayúcar, and A. Hernández, "Study of the presence of fluorine in the recycled fractions during carbothermal treatment of EAF dust," Waste Management, vol. 23, no. 6, pp. 483-491, 2003.

[27] Y. Song, J. Qian, Z. Wang, and Z. Wang, "Self-cementing mechanism of CFBC coal ashes at early ages," Journal of Wuhan University of Technology-Mater, vol. 23, no. 3, pp. 338-341, 2008.

[28] Y. Shen, J. Qian, and Z. Zhang, "Investigations of anhydrite in CFBC fly ash as cement retarders," Construction and Building Materials, vol. 40, pp. 672-678, 2013.

[29] G. Sheng, Q. Li, and J. Zhai, "Investigation on the hydration of CFBC fly ash,” Fuel, vol. 98, pp. 61-66, 2012.

[30] J. Temuujin, R. P. Williams, and A. van Riessen, "Effect of mechanical activation of fly ash on the properties of geopolymer cured at ambient temperature," Journal of Materials Processing Technology, vol. 209, no. 12-13, pp. 5276-5280, 2009.

[31] P. Chindaprasirt, U. Rattanasak, and C. Jaturapitakkul, "Utilization of fly ash blends from pulverized coal and fluidized bed combustions in geopolymeric materials," Cement and Concrete Composites, vol. 33, no. 1, pp. 55-60, 2011.

[32] P. Jiahui, Z. Jianxin, Q. Jindong, B. Leng, and W. Tizhi, "Influence of sodium sulfate on anhydrite hydration process and morphology of its dihydrate products," Journal of the Chinese Ceramic Society, vol. 36, no. 10, pp. 1356-1361, 2008. 


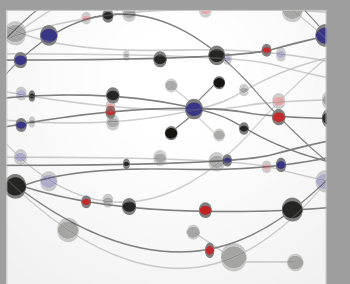

The Scientific World Journal
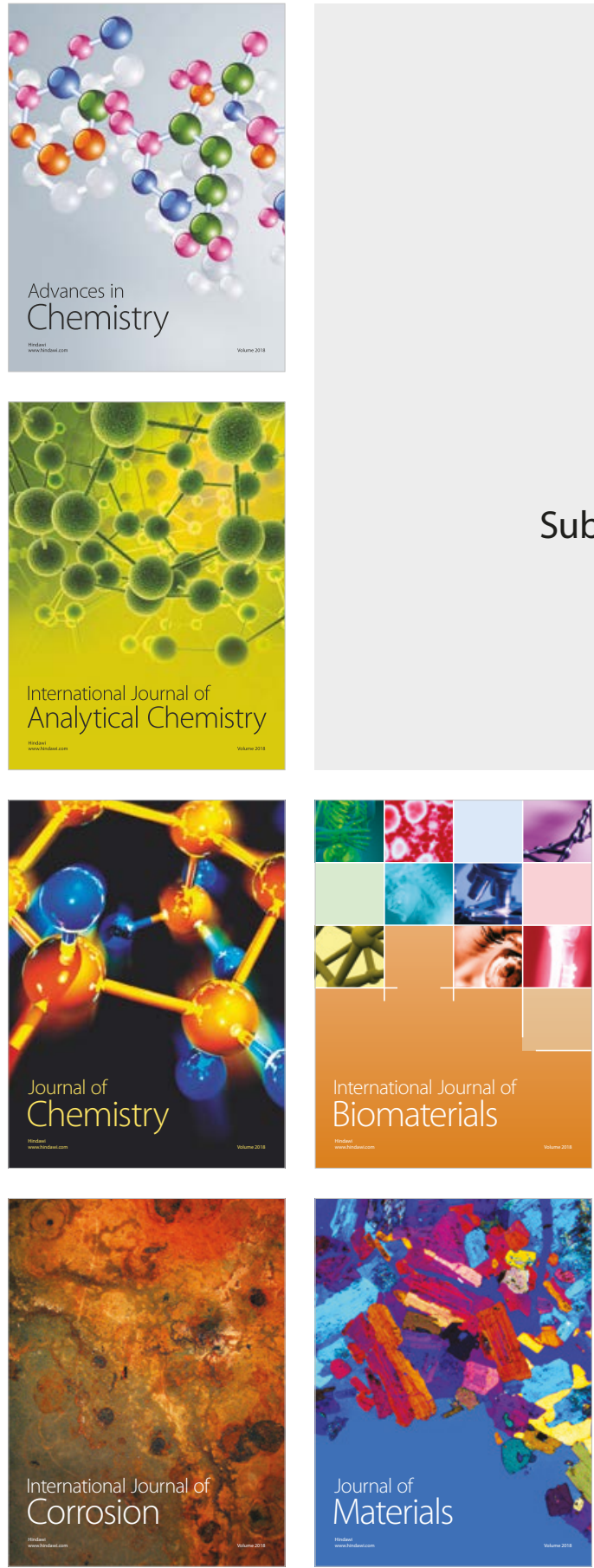

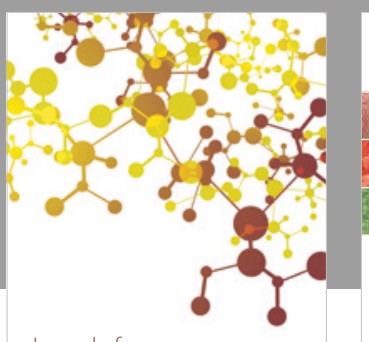

Journal of

Applied Chemistry
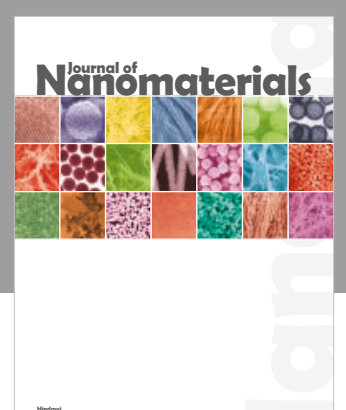

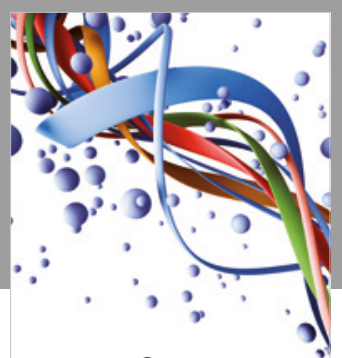

Scientifica

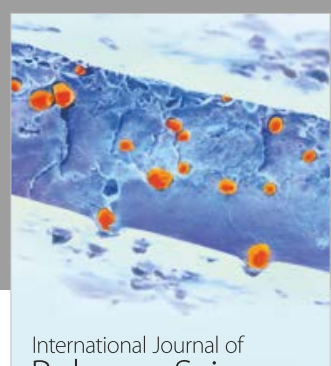

Polymer Science

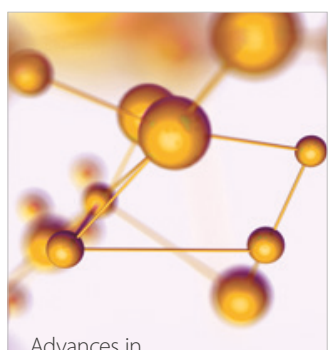

Physical Chemistry
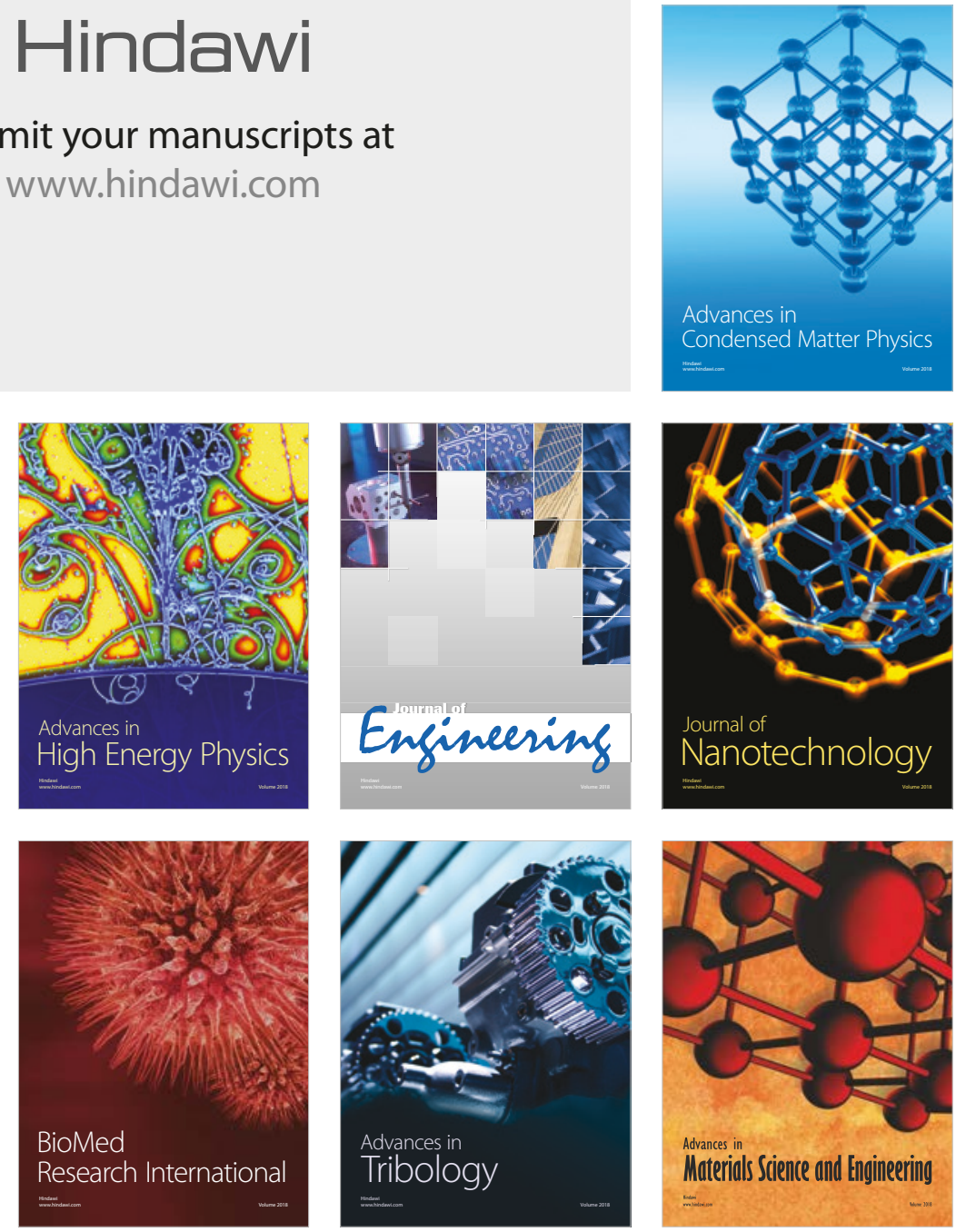